\title{
Analysis of Agro-Morphological Characters in Wheat (Triticum aestivum L.) Genotypes for Yield and Yield Components
}

\author{
Lutfullah Safi, Rajesh Singh* and Thomas Abraham
}

Department of Agronomy, Sam Higginbottom Institute of Agriculture, Technology and Sciences, Allahabad, (UP) 211 007, India

*Corresponding author

\section{A B S T R A C T}

\begin{tabular}{|l|}
\hline Ke y w or d s \\
$\begin{array}{l}\text { Agro- } \\
\text { morphological } \\
\text { charaters, Wheat, } \\
\text { Yield. }\end{array}$ \\
\hline Article Info \\
\hline $\begin{array}{l}\text { Accepted: } \\
\text { 04 July 2017 } \\
\text { Available Online: } \\
\text { 10 September } 2017\end{array}$ \\
\hline
\end{tabular}

The present experiment was conducted to evaluate the yield and yield components of 30 wheat varieties for identification desirable genotypes. Two consecutive rabi cropping seasons of 2014-15 and 2015-16 trial was carried out at Crop Research Farm (CRF) of department of Agronomy. Morphological data for agronomic characters were recorded for plant height $(\mathrm{cm})$, number of spikelets spike ${ }^{-1}$, number of grains spike ${ }^{-1}, 1000$-grain weight, grain yield and harvest index. The analysis of variance for agronomic traits (plant height, number of spikelets spike ${ }^{-1}$ number of grains spike ${ }^{-1}, 1000$-grain weight, grain yield and harvest index) revealed significant variation in first cropping season, number of grains per spike was non-significant in second cropping season and number of spikelets spike ${ }^{-1}$ was non-significant in second cropping season as well as in pooled data. Majority of the wheat genotypes possessed yield higher levels. Higher yielding varieties had recorded higher values of harvest index. The present study demonstrated high grain yield genotypes possessed the combination of other agronomic desirable characters.

\section{Introduction}

Wheat (Triticum aestivum L.) is one of the major staple food crops grown worldwide on more than $17 \%$ of the cultivated land and produced in a wide range of climatic environments systems, where and geographic regions (Gupta et al., 2008). It is the leading cereal grain produced, consumed and traded in the world. India harvested a record 86.53 million tonnes of wheat during the crop year 2014-15 (DWR, Annual Report, 2016). India witnessed the dramatic successes of the green revolution and has been able to rise from a deficit state to a self-sufficient one going on to have surplus production at times. This is indeed an important and reassuring milestone.
During the past four decades, wheat has made a significant contribution to the increase in global food production as total production rose steadily through the use of higher yielding, water- and fertilizer-responsive, and disease-resistant varieties supported by a strengthened input system, tailored management practices and improved marketing (Dixon et al., 2009).

Morphological and agronomic characters of wheat have a special role in determining the importance of each trait in increasing yield, so these traits were used in breeding programs which at least led to improving yield and 
introducing commercial varieties (Mollasadeghi et al., 2011).

Improvement of wheat yield based on breeding concept and use of large number of germplasm and best cultivars as a parent. The success in breeding process is not simple because of complex relationships between grain yield and yield components. Some of yield components are in positive correlation and other in a negative correlation which presents difficulties in efficiency of selection genotypes for yield. The wheat yield is affected by many factors: genetic, environment and theirs interaction. The value of yield varied in dependence of yield components such as stem height, leaf area, spike length, number of spikelets per spike and number of kernels per spike were also found associated with the vegetative growth period (Knezevic et al., 2012). Agronomicaly important traits are valuable for a species in cultivation and form the basis for the breeder's selection of promising plant material. Number of kernels per spike associated by the number of spikelets per spike which have direct connection with productivity in wheat (Knezevic et al., 2007). Days to heading, spike number per square meter, flag-leaf area and grain yield are mainly controlled by environmental variance, like temperatures and water stresses in post-anthesis period which have influence on reduction of kernels developing and filling in wheat as a result both grain weight and grain number are found to decline (Mohammadi et al., 2011). The two most frequently cited factors contributing to the increase in grain yield are improved cultivars and fertilizer application. Yield contributors i.e. effective tillers per plant, grain yield and biological yield increase with the progressive increase in fertilizer dosage (Abraham and Lal, 2004).

The present study was performed to evaluate the yield and yield components of 30 wheat varieties for identification desirable genotypes for further utilization in plant breeding programs.

\section{Materials and Methods}

The experiment was conducted during two consecutive rabi cropping seasons of 2014-15 and 2015-16 at Crop Research Farm, Department of Agronomy, Allahabad School of Agriculture, SHIATS, Allahabad (UP), which is located at 25024 ' 42" N latitude, 810 50 ' 56" E longitude and $98 \mathrm{~m}$ altitude above the mean sea level. The soil $\mathrm{pH}$ was 7.5 and 7.4 with an electrical conductivity (EC) of $0.10 \mathrm{dSm}^{-1}$ and $0.10 \mathrm{dSm}^{-1}$ in 2015 and 2016, respectively. The organic carbon content was $0.40 \%$ during both the years. The soil available phosphorus was analyzed to be (18.90 and $\left.17.80 \mathrm{~kg} \mathrm{ha}^{-1}\right)$ and available potassium was analyzed $(292.10$ and $327.3 \mathrm{~kg}$ $\mathrm{ha}^{-1}$ ) in 2015 and 2016 respectively. The experiment was laid out in Randomized Block Design replicated thrice. Thirty wheat genotypes were included in the study, given in table 1 . Genotypes were grown in a plot size of $1.2 \mathrm{~m} \times 2.5 \mathrm{~m}$ ( 6 rows of $2.5 \mathrm{~m}$ length with $20 \mathrm{~cm}$ space between rows) with seed rate of $12 \mathrm{~g} / \mathrm{m}^{2}$.

Optimum dose of Nitrogen, Phosphorus, and Potassium i.e. @ 120,60, $40 \mathrm{~kg} / \mathrm{ha}$ was used respectively at the time of seed bed preparation and crop growth periods. Sowing was done by hand drilling and covered lightly with soil. Five irrigations were applied at critical stages; $1^{\text {st }}, 2^{\text {nd }}, 3^{\text {rd }}$ and $4^{\text {th }}$ irrigation was given at 24, 50, 75 and 105 DAS, respectively. All other agronomic practices are done as recommended for wheat production in the area. Morphological data on plant height $(\mathrm{cm})$, number of spikelets spike ${ }^{-1}$, number of grains spike ${ }^{-1}, 1000$-grain weight $(\mathrm{g})$, grain yield $\left(\mathrm{t} \mathrm{ha}^{-1}\right)$ and harvest index $(\%)$ were recorded manually in each genotype per replication. 


\section{Results and Discussions}

The two years data associated with their pooled data is presented in table $2 \mathrm{a}$ and $2 \mathrm{~b}$. It is observed that among the agronomic traits, almost all traits were significant during both of the experimental years. Traits such as, plant height, 1000- grains weight, grain yield $\left(\mathrm{t} \mathrm{ha}^{-1}\right.$ ) and harvest index (\%), were significant across the years as well as their pooled. Only, two traits number of spikelets spike $^{-1}$ and number of grains spike ${ }^{-1}$ showed non- significant variation in 2016 and the pooled data of number of grains spike ${ }^{-1}$ was found to be non- significant.

During first and second experimental years as well as pooled data minimum plant height $(78.4 \mathrm{~cm}, 79.3 \mathrm{~cm}$ and $78.9 \mathrm{~cm}$ ) was recorded under K 8020. All most all genotypes was found to have normal plant height, however, the HUW 251 and HUW 213 genotypes have recorded higher plant height. Wheat plant height is considered as an important trait, since taller cultivars are more vulnerable to lodging than medium or short stature cultivars. There was significant variation among the genotypes for this trait, so selection within the genotype can be done for the promise varieties. Similar findings have been reported by Munsif et al., (2015).

Number of spikelets spike ${ }^{-1}$ showed wide range of variation. Genotype HUW251 recorded to have higher (18.7) number of spikelets spike $^{-1}$ in first cropping seasons, while genotype Raj1972 recorded maximum number of spikelets spike $^{-1}$ in second cropping season as well as in pooled data of two cropping seasons (18.9) and (18.7) respectively. Number of spikelets spike ${ }^{-1}$ plays a very important role in the possible increase of grain yield of wheat because it significantly affects the grain number and grain mass per spike in wheat. Therefore, best performing genotypes of this study can be selected and incorporated for further breeding program. Similar findings have also been reported by Zecevic et al., (2009) and Amagai, et al., (2014).

Number of grains spike ${ }^{-1}$ showed significant differences in the first cropping season only, while it was non-significant in second cropping season as well as in pooled data, which could be due to environmental factor. Highest number of grains spike ${ }^{-1}$ (48.9) was recorded under HD2385 genotype in the first cropping season. Number grain spike ${ }^{-1}$ is the main yield component in the cereal crops as well as in wheat. Improvement in number grain spike ${ }^{-1}$ is important to achieve genetic gains in wheat yield. Number of grain spike ${ }^{-1}$ is dependent on floret production and survival from flag leaf initiation period to anthesis when the grain number spike ${ }^{-1}$ is determined. Similar findings have been reported by (Knezevic, et al., 2012) and (Farooq, et al., 2011).

Significant differences were observed among genotypes for 1000-grain weight. Maximum value of 1000-grain weight was recorded for genotype HD2687 and HD2278 (44.5 g) and $(48.6 \mathrm{~g})$ in first and second cropping seasons respectively, while genotype K8020 had recorded higher value (45.1 g) of 1000-grain weight in pooled of two years data. 1000grain weight is one of the most 1000-grain weight is wheat major yield traits and grading parameter that measure the agronomic yield of a wheat cultivars. Enhancing grain size in wheat breeding programs can improve grain weight to increase crop yield important yield components and could be used as potential selection criteria for grain yield. Similar findings have also been reported by Ghuttai $e t$ al., (2015) and Ramya et al., (2010).

Genotype HD1941 showed maximum grain yield $\left(4.9 \mathrm{t} \mathrm{ha}^{-1}\right)$ in the first cropping season and genotype K9162 showed maximum grain 
yield $\left(4.4 \mathrm{t} \mathrm{ha}^{-1}\right)$ in second cropping season, while for pooled of two years, genotype HUW37 showed higher value $\left(4.5 \mathrm{t} \mathrm{ha}^{-1}\right)$. Grain yield is a complex quantitative trait and it is directly or indirectly influence by other plant traits. Ultimate goal of any wheat breeding is to get maximum yield. The most important task of wheat breeding is to develop cultivars possessing high genetic yield potential. Grain yield is a complex inherited trait associated with combination of several plant characteristics. Similar findings have also been reported by Longove et al., (2014) and Ali et al., (2007).

Table.1 List of wheat genotypes and their pedigree

\begin{tabular}{cll}
\hline No. & Genotypes & Pedigree/Parentage \\
\hline 1 & HD 1982 & YT54/N10B//HD845 \\
2 & HD2643 & VEE'` $\% /$ HD2407 //HD 2329 \\
3 & HD2428 & HD1949 /HD2160 \\
4 & HD2402 & HD2177//CNO67/BB/3/HD2160/4/HD2236 \\
5 & HD2204 & HD 2092 //HD 1962/E 4870/K 65 \\
6 & HD 2891 & WL711 // HD 2624 \\
7 & HD 2177 & HD1962-E 4870-K65/HD1593 \\
8 & HD 2385 & HI686/ HD 2263 \\
9 & HD 2270 & HD 1962/E4870/ K65/HD 2119 /247 \\
10 & HD 2236 & HD 2119 / HD 1981 \\
11 & HD 2278 & HD 2119 //HD 1912 /HD 1592/3/HD 1962/E 4870/4/ K65 \\
12 & HD 2954 & DL 975-1/BAVIOCRA \\
13 & HD 2824 & PTO-1 / CNO 79 / PRL /GAA /3/HD 1951 \\
14 & HD 1941 & E 5477 * S64 \\
15 & HD 2687 & CPAN 2009 / HD 2329 \\
16 & HUW 37 & KALYANSONA / S 331 // HD 1982 \\
17 & HUW 318 & HUW 206 / HUW 202 \\
18 & HUW 251 & WH-147/HD-2160//2*WH-147 \\
19 & HUW 213 & NORTENO / MOTI // HD 2160 \\
20 & HUW 55 & E 4870 / HD 1982 // INIA 66 /HD 2189 \\
21 & K 88 & VEERY "S" / WL 711 \\
22 & K 9162 & K 7827/HD 2204 \\
23 & K 9006 & CPAN 1687 /HD 2204 \\
24 & K 9533 & HI 1077/HUW 234 \\
25 & K 8020 & KALYANSONA/HD 1982 \\
26 & Raj 3765 & HD 2402/VL639 \\
27 & Raj 6560 & TOPDY 6 \\
28 & Raj 3077 & HD 2267/RAJ 1482/5/BB/INIA66'S'/NAPO \\
29 & Raj 1555 & COCORIT'S' / RAJ 911 \\
30 & Raj 1972 & HD 2195 / HD 2160 \\
\hline & & \\
& & \\
\hline
\end{tabular}


Int.J.Curr.Microbiol.App.Sci (2017) 6(9): 578-585

Table.2a Mean performance of thirty wheat genotypes for different agronomic traits

\begin{tabular}{|c|c|c|c|c|c|c|c|c|c|c|}
\hline \multirow{2}{*}{ S. No. } & \multirow{2}{*}{ Genotypes } & \multicolumn{3}{|c|}{ Plant height } & \multicolumn{3}{|c|}{ Number of spikelets spike ${ }^{-1}$} & \multicolumn{3}{|c|}{ Number of grains spike ${ }^{-1}$} \\
\hline & & 2015 & 2016 & Pooled & 2015 & 2016 & Pooled & 2015 & 2016 & Pooled \\
\hline 1 & HD 1982 & 104.8 & 104.3 & 104.5 & 18.1 & 17.5 & 17.8 & 48.1 & 40.9 & 44.5 \\
\hline 2 & HD 2643 & 86.6 & 85.3 & 85.9 & 17.3 & 17.5 & 17.4 & 42.3 & 45.9 & 44.1 \\
\hline 3 & HD 2428 & 87.1 & 93.3 & 90.2 & 18.3 & 18.7 & 18.5 & 39.5 & 41.5 & 40.5 \\
\hline 4 & HD 2402 & 84.9 & 86.3 & 85.6 & 17.3 & 17.1 & 17.2 & 37.9 & 42.2 & 40.0 \\
\hline 5 & HD 2204 & 85.6 & 87.8 & 86.7 & 18.2 & 17.9 & 18.1 & 41.4 & 39.5 & 40.4 \\
\hline 6 & HD 2891 & 87.3 & 89.9 & 88.6 & 17.5 & 18.1 & 17.8 & 44.7 & 42.1 & 43.4 \\
\hline 7 & HD 2177 & 83.1 & 83.3 & 83.2 & 16.7 & 16.2 & 16.5 & 42.9 & 43.1 & 43.0 \\
\hline 8 & HD 2385 & 87.2 & 85.8 & 86.5 & 18.2 & 18.2 & 18.2 & 48.9 & 39.9 & 44.4 \\
\hline 9 & HD 2270 & 83.1 & 80.9 & 82.0 & 18.1 & 17.9 & 18.0 & 40.5 & 43.5 & 42.0 \\
\hline 10 & HD 2236 & 92.7 & 92.9 & 92.8 & 18.6 & 18.5 & 18.5 & 43.1 & 45.5 & 44.3 \\
\hline 11 & HD 2278 & 92.5 & 93.1 & 92.8 & 17.7 & 17.8 & 17.7 & 44.1 & 45.5 & 44.8 \\
\hline 12 & HD 2954 & 88.2 & 88.9 & 88.6 & 16.6 & 17.3 & 16.9 & 42.0 & 38.9 & 40.5 \\
\hline 13 & HD 2824 & 91.5 & 90.3 & 90.9 & 18.2 & 18.2 & 18.2 & 46.2 & 39.8 & 43.0 \\
\hline 14 & HD 1941 & 90.2 & 84.6 & 87.4 & 17.7 & 16.9 & 17.3 & 43.4 & 40.2 & 41.8 \\
\hline 15 & HUW 37 & 81.3 & 83.1 & 82.2 & 17.5 & 17.4 & 17.5 & 41.1 & 43.7 & 42.4 \\
\hline 16 & HUW 318 & 83.5 & 80.7 & 82.1 & 18.1 & 17.1 & 17.6 & 40.5 & 40.4 & 40.4 \\
\hline 17 & HUW 251 & 113.0 & 114.1 & 113.6 & 18.7 & 17.5 & 18.1 & 43.1 & 38.3 & 40.7 \\
\hline 18 & HUW 213 & 112.9 & 113.2 & 113.0 & 16.9 & 18.8 & 17.8 & 46.3 & 46.7 & 46.5 \\
\hline 19 & HUW 55 & 85.9 & 87.7 & 86.8 & 17.0 & 17.9 & 17.5 & 48.7 & 42.1 & 45.4 \\
\hline 20 & K 88 & 81.2 & 83.4 & 82.3 & 17.5 & 17.1 & 17.3 & 38.4 & 40.1 & 39.2 \\
\hline 21 & K 9006 & 95.7 & 94.7 & 95.2 & 17.7 & 17.9 & 17.8 & 38.5 & 40.9 & 39.7 \\
\hline 22 & K 9533 & 94.0 & 93.9 & 94.0 & 16.6 & 18.5 & 17.5 & 41.4 & 40.6 & 41.0 \\
\hline 23 & K 8020 & 78.4 & 79.3 & 78.9 & 17.5 & 17.9 & 17.7 & 40.7 & 44.0 & 42.4 \\
\hline 24 & Raj 3765 & 104.1 & 105.9 & 105.0 & 18.2 & 17 & 17.6 & 44.9 & 42.5 & 43.7 \\
\hline 25 & Raj 6560 & 97.9 & 99.0 & 98.5 & 15.9 & 17.9 & 16.9 & 44.3 & 41.3 & 42.8 \\
\hline 26 & Raj 3077 & 87.6 & 93.7 & 90.7 & 17.4 & 19.3 & 18.3 & 45.9 & 46.5 & 46.2 \\
\hline 27 & Raj 1555 & 94.3 & 93.6 & 93.3 & 18.2 & 17.8 & 18.0 & 42.7 & 45.9 & 44.3 \\
\hline 28 & Raj 1972 & 92.5 & 91.0 & 91.8 & 18.6 & 18.9 & 18.7 & 43.1 & 43.7 & 43.4 \\
\hline 29 & HD $2687(\mathrm{C} 1)$ & 91.2 & 85.0 & 88.1 & 16.5 & 17.8 & 17.1 & 43.3 & 39.6 & 41.4 \\
\hline \multirow[t]{3}{*}{30} & K 9162 (C2) & 94.4 & 92.9 & 93.7 & 17.5 & 18.6 & 18.1 & 40.7 & 42.3 & 41.5 \\
\hline & SEd $( \pm)$ & 1.55 & 1.16 & 0.98 & 0.76 & 0.86 & 0.57 & 2.97 & 3.84 & 2.95 \\
\hline & $\mathrm{CD}(\mathrm{P}=0.05)$ & 3.1 & 1.32 & 1.96 & 1.53 & NS & 1.14 & 5.95 & NS & NS \\
\hline
\end{tabular}


Int.J.Curr.Microbiol.App.Sci (2017) 6(9): 578-585

Table.2b Mean performance of thirty wheat genotypes for different agronomic traits

\begin{tabular}{|c|c|c|c|c|c|c|c|c|c|c|}
\hline \multirow{2}{*}{ S. No. } & \multirow{2}{*}{ Genotypes } & \multicolumn{3}{|c|}{ 1000-grains weight (g) } & \multicolumn{3}{|c|}{ Grain yield $\left(\mathrm{t} \mathrm{ha}^{-1}\right)$} & \multicolumn{3}{|c|}{ Harvest index (\%) } \\
\hline & & 2015 & 2016 & Pooled & 2015 & 2016 & Pooled & 2015 & 2016 & Pooled \\
\hline 1 & HD 1982 & 38.7 & 41.9 & 40.3 & 3.2 & 3.5 & 3.3 & 26.4 & 28.8 & 27.6 \\
\hline 2 & HD 2643 & 44.3 & 45.5 & 44.9 & 3.9 & 3.6 & 3.8 & 33.0 & 30.9 & 31.9 \\
\hline 3 & HD 2428 & 43.7 & 44.5 & 44.1 & 4.5 & 3.7 & 4.1 & 35.8 & 29.8 & 32.8 \\
\hline 4 & HD 2402 & 38.5 & 47.1 & 42.8 & 4.1 & 4.0 & 4.0 & 35.3 & 33.7 & 34.5 \\
\hline 5 & HD 2204 & 37.6 & 44.3 & 41.0 & 3.1 & 2.8 & 2.9 & 30.3 & 24.4 & 27.4 \\
\hline 6 & HD 2891 & 43.8 & 46.2 & 45.0 & 3.2 & 3.4 & 3.3 & 28.1 & 28.6 & 28.4 \\
\hline 7 & HD 2177 & 41.3 & 39.4 & 40.3 & 3.7 & 3.3 & 3.5 & 30.0 & 28.6 & 29.3 \\
\hline 8 & HD 2385 & 41.8 & 36.9 & 39.4 & 3.6 & 4.3 & 3.9 & 33.2 & 36.4 & 34.8 \\
\hline 9 & HD 2270 & 37.6 & 44.1 & 40.8 & 4.0 & 3.7 & 3.8 & 34.5 & 31.7 & 33.1 \\
\hline 10 & HD 2236 & 43.8 & 44.2 & 44.0 & 2.8 & 3.1 & 3.0 & 23.2 & 25.4 & 24.3 \\
\hline 11 & HD 2278 & 41.0 & 48.6 & 44.8 & 3.8 & 3.5 & 3.7 & 33.3 & 29.4 & 31.4 \\
\hline 12 & HD 2954 & 35.4 & 42.0 & 38.7 & 3.8 & 3.6 & 3.7 & 30.3 & 28.4 & 29.3 \\
\hline 13 & HD 2824 & 43.6 & 44.4 & 44.0 & 3.0 & 4.3 & 3.7 & 30.0 & 38.5 & 34.2 \\
\hline 14 & HD 1941 & 40.5 & 39.5 & 40.0 & 4.9 & 3.7 & 4.3 & 39.7 & 30.4 & 35.1 \\
\hline 15 & HUW 37 & 42.6 & 39.7 & 41.2 & 4.1 & 4.8 & 4.5 & 34.6 & 40.1 & 37.4 \\
\hline 16 & HUW 318 & 38.6 & 40.1 & 39.3 & 2.8 & 2.6 & 2.7 & 37.5 & 27.3 & 32.4 \\
\hline 17 & HUW 251 & 42.8 & 45.2 & 44.0 & 3.9 & 3.9 & 3.9 & 31.7 & 33.8 & 32.7 \\
\hline 18 & HUW 213 & 40.1 & 43.2 & 41.7 & 3.5 & 3.6 & 3.6 & 27.9 & 30.1 & 29.0 \\
\hline 19 & HUW 55 & 38.8 & 43.7 & 41.2 & 4.1 & 3.9 & 4.0 & 36.5 & 35.5 & 36.0 \\
\hline 20 & K 88 & 32.0 & 42.0 & 37.0 & 3.1 & 4.1 & 3.6 & 31.5 & 38.8 & 35.1 \\
\hline 21 & K 9006 & 41.0 & 38.7 & 39.8 & 4.2 & 3.0 & 3.6 & 27.0 & 19.1 & 23.1 \\
\hline 22 & K 9533 & 42.0 & 42.1 & 42.1 & 4.7 & 4.1 & 4.4 & 38.6 & 34.4 & 36.5 \\
\hline 23 & K 8020 & 42.2 & 48.1 & 45.1 & 3.9 & 4.5 & 4.2 & 33.8 & 38.8 & 36.3 \\
\hline 24 & Raj 3765 & 42.9 & 37.9 & 40.4 & 4.1 & 3.2 & 3.7 & 32.8 & 25.9 & 29.4 \\
\hline 25 & Raj 6560 & 37.8 & 40.5 & 39.1 & 3.7 & 3.6 & 3.6 & 30.0 & 29.0 & 29.5 \\
\hline 26 & Raj 3077 & 39.0 & 41.0 & 40.0 & 4.0 & 3.9 & 4.0 & 35.3 & 33.1 & 34.2 \\
\hline 27 & Raj 1555 & 43.7 & 42.2 & 42.9 & 4.0 & 4.3 & 4.2 & 32.2 & 34.6 & 33.4 \\
\hline 28 & Raj 1972 & 39.0 & 39.3 & 39.2 & 3.5 & 3.6 & 3.6 & 28.6 & 29.1 & 28.9 \\
\hline 29 & HD 2687 & 44.5 & 42.9 & 43.7 & 4.3 & 4.0 & 4.1 & 37.0 & 33.7 & 35.3 \\
\hline \multirow[t]{3}{*}{30} & K 9162 & 45.4 & 34.6 & 40.0 & 4.2 & 4.4 & 4.3 & 33.1 & 36.6 & 34.9 \\
\hline & $\operatorname{SEd}( \pm)$ & 1.5 & 2.03 & 1.17 & 0.28 & 0.19 & 0.17 & 2.66 & 2.1 & 1.65 \\
\hline & $\mathrm{CD}(\mathrm{P}=0.05)$ & 3.01 & 4.06 & 2.34 & 0.56 & 0.38 & 0.34 & 5.32 & 4.21 & 3.3 \\
\hline
\end{tabular}


Maximum value for harvest index was recorded for genotype HD1941 (39.7\%) in the first cropping season, while in the second cropping season and pooled of the two years, the higher values of harvest index were recorded for genotype HUW37 as (40.1\% and $37.4 \%$ ) respectively. Harvest index has direct effect on grain yield. Enhancing in harvest index will boost grain yield. Similar findings have also been reported by (Dai, et al., 2016) and (Ahmad, et al., 2010).

Finally, from the present finding it is concluded that the wheat varieties used in the present study showed that there was significant different among the genotype. High yield wheat genotypes possessed better agronomic performance in all yield related attributes across the yeas such as, number of spikelets per spike, number of grains per spike, 1000-grain weight and higher harvest index value. As a whole the study was efficient and the promising genotypes can be used in future wheat breeding programme.

\section{References}

Abraham, T., and Lal, R.B. 2004. Effect of integrated nutrient management of production of wheat (Triticum aestivum L.) and soil fertility in a legume based cropping system. Indian J. of Agri. Res., 38:178-183.

Ahmad, B., Khalil, I.H., Iqbal, M. and Rahman, H. 2010. Genotypic and phenotypic correlation among yield components in bread wheat under normal and late plantings. Sarhad J. Agri., 26(2): 260-265.

Ali, S., Ali-Shah, S. M. Hassnain, A. Shah, Z. and Munir I. 2007. Genotypic variation for yield and morphological traits in wheat. Sarhad J. Agri., 23(4) 943-946.

Amagai, Y., Aliyeva, A. J., Khaminov, N., Martinek, P., Watanabe, N. and Kuboyama, T. 2014. Microsatellite mapping of the genes for sham ramification and extra glume in spikelets of tetraploid wheat. Genet Res. Crop Evolution. 61: 465-47.

Dai, J., Bean, B., Brown, B., Bruening, W., Edwards, J., Flowers, M., Karow, R., Lee, C., Morgan, G., Ottman M. Ransom J. and Wiersma, J. 2016. Harvest index and straw yield of five classes of wheat. Biomass Bioenergy 85: 223-227.

Directorate of Wheat Research Annual Report, 2016. www.dwr.org

Dixon, J., Braun, H.J. Crouch, J. 2009. Overview: transitioning wheat research to serve the future needs of the developing world. In: Dixon J, Braun $\mathrm{H}$ J, Kosina P., Crouch J., (eds). Wheat facts and futures. Mexico, D.F: CIMMYT.

Farooq, M., Bramley, H., Palta, J. A. and Siddique K.H.M. 2011. Heat stress in wheat during reproductive and grainfilling phases. Critical Reviews in Plant Sci., 30:1-17.

Ghuttai, G., Mohammad, F., Khan, F. U., Khan, W. U. and Zafar, F. Z. 2015. Genotypic differences and heritability for various polygenic traits in F5 wheat populations. American-Eurasian J. Agri. Environ. Sci., 15 (10): 2039-2044

Gupta, P.K., Mir, R.R. Mohan, A. and Kumar J. 2008. Wheat genomics: Present status and future prospects. International $J$. Plant Genomics. Pp. 1-36.

Knezevic, D., Paunovic, A. Madic, M. and Djukic, N. 2011. Genetic analysis of nitrogen accumulation in four wheat cultivars and their hybrids. Cereal Res. Communication, 35: 633-636 (2007).

Knezevic, D., Zecevic, V., Stamenkovic, S., Atanasijevic, S. and Milosevic, B. 2012. Variability of number of kernels per spike in wheat cultivars (Triticum aestivum L.). J. Central European Agri., 13(3): 608-614 
Longove, M.A., Akbar, F., Baqa, S. and Azam, S. 2014. Performance evaluation of different wheat varieties under agroecological conditions of Quetta (Balochistan). J., Biology, Agri. Healthcare, 4: 3-43.

Mohammadi, M., Karimizadeh, R. Shefazadeh, M.K. and Sadeghzadeh, B. 2011. Statistical analysis of durum wheat yield under semi-warm dry land condition. Australian Journal Crop Sci., 5: 1292-1297.

Mollasadeghi, V., Imani, A.A. Shahryari, R. and Khayatnezhad, M. 2011. Classifying bread wheat genotypes by multivariable statistical analysis to achieve high yield under after anthesis drought. Middle East J. Sci. Res., 7: 217-220.
Munsif, F., Arif, M., Jan, M.T. Ali, K. and Khan, M.J. 2015. Influence of sowing dates on phenol-ogical development and yield of dual purpose wheat cultivars. Pak. J. Bot., 47(1): 83-88.

Ramya, P., Chaubal, A., Kulkarni, K., Gupta, L., Kadoo, N., Dhaliwal, H.S., Chhunejam, P., Lagu, M. and Gupta, V. 2010. QTL mapping of 1000-kernel weight, kernel length, kernel width in bread wheat (Triticum aestivum L.). J. Applied Genetics 51:421-429

Zecevic, V., Knezevic, D., Boskovic, J., Micanovic, D. and Di-Mitrijevic, B. 2009. Genetic and phenotypic variability of number of spikelets per spike in winter wheat. Kragujevac $J$. Sci., 31: 85-90.

\section{How to cite this article:}

Lutfullah Safi, Rajesh Singh and Thomas Abraham. 2017. Analysis of Agro-Morphological Characters in Wheat (Triticum aestivum L.) Genotypes for Yield and Yield Components. Int.J.Curr.Microbiol.App.Sci. 6(9): 578-585. doi: https://doi.org/10.20546/ijcmas.2017.609.070 